Interactive comment on "Stratospheric aerosol layer perturbation caused by the $\mathbf{2 0 1 9}$ Raikoke and Ulawun eruptions and climate impact" by Corinna

\title{
Kloss et al.
}

\section{Anonymous Referee \#1}

Received and published: 3 September 2020

The comment was uploaded in the form of a supplement:

https://acp.copernicus.org/preprints/acp-2020-701/acp-2020-701-RC1-

supplement.pdf

Interactive comment on Atmos. Chem. Phys. Discuss., https://doi.org/10.5194/acp-2020-701, 2020. 